\title{
Pityriasis rotunda: A case from Morocco
}

\section{Selma El Kadiri, Hanane Bay Bay, Rhizlane Chaoui, Zakia Douhi, Sara Elloudi, Fatima Zahra Mernissi}

\author{
Department of Dermatology, University Hospital Hassan II, Fez, Morocco
}

Corresponding author: Dr. Selma El Kadiri, E-mail: elkadiri-s@hotmail.com

Sir,

Pityriasis Rotunda or pityriasis circinata is a rare cutaneous disorder with a preponderance of reports in black population, Japanese, Koreans and italians [1]. It manifests with circular, well-limited, scaly, hypo - or hyperpigmented plaque in the trunk and limbs [2]. Here we report a new observation from Morocco.

A 45-year-old female with no personal or familial history of skin or systemic diseases presented to our Department for long-standing itching lesions of the proximal limbs. Clinical examination showed hyperpigmented scaly, circular, fine plaques over the hips and limbs with sharp demarcation between the lesional area and the normal surrounding skin (Figs. 1 and 2). We suspected clinically the diagnosis of plaque parapsoriasis or tinea corporis considering anamnesis and clinical aspect. Dermoscopy revealed polygonal brownish scales separated by fine whitish striae (Fig. 3). Skin biopsy revealed a hyperkeratosis, a decrease in the granular layer and hyperpigmentation of the basal cell layer compatible with the diagnosis of Pityriasis Rotunda, urinary and hepatic tests were normal. Chest $\mathrm{x}$-ray and abdominopelvic ultrasonography were normal. The patient was treated with emollient and keratolytic creams with good improvement.

Pityriasis Rotunda is well known in Japan, Italy and South Africa. Its exact pathogeny remains unknown [2]. However, the hypothesis of possible relation to susceptible patients with a systemic disorder has been suggested. Additionally to that, an absence of profilaggrin $\mathrm{N}$-terminal domain in affected area has been demonstrated in a Japanese patient with pityriasis
Rotunda [3]. Clinically, it is characterized by polycyclic, moderately hyper or hypopigmented, scaly patches with a sharp demarcation. Type I is said to be associated with intenral malignancy in blacks and Asians. The type II is more common in Caucasians with a familial history

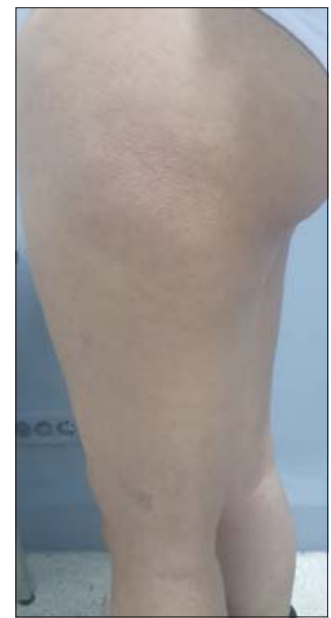

Figure 1: Cicular scaly hypeprigmented patch Icalized in the hips.

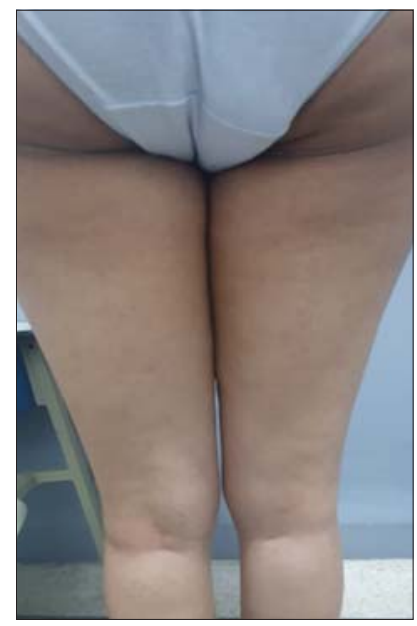

Figure 2: Pityriasis rotunda in the limbs.

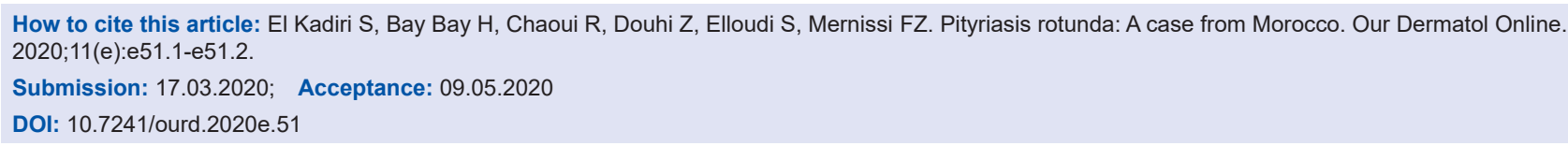




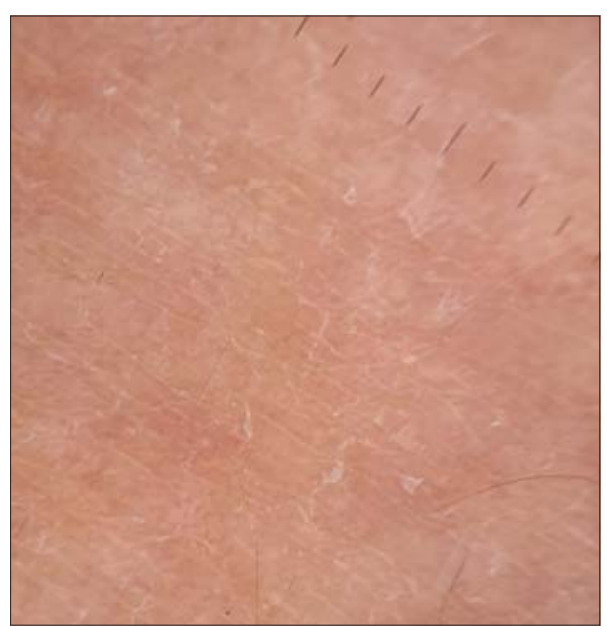

Figure 3: Dermoscopy showing brownish background with polygonal scales sperated by fine striae.

of the disorder with no malignancy [4]. Microscopic features of Pityriasis Rotunda are similar to ichtyosis with a decreased granular cell layer, hyperkatosis and increased basal cell layer pigmentation [2]. This entity can be confused with tinea versicolor, tinea corporis, leprosy and large plaque parapsoriasis [3]. The chronic evolution of this entity by relapses with possibility of spontaneous resolution could suggest a therapeutic abstention. Several cases have reported improvement with keratolytic emollients (lactic acid and salicylic acid), topical tretinoin cream $0.1 \%$ and treating the underlying systemic disease [5].

\section{Consent}

The examination of the patient was conducted according to the Declaration of Helsinki principles.

The authors certify that they have obtained all appropriate patient consent forms. In the form the patient(s) has/have given his/her/their consent for his/her/their images and other clinical information to be reported in the journal. The patients understand that their names and initials will not be published and due efforts will be made to conceal their identity, but anonymity cannot be guaranteed.

\section{REFERENCES}

1. Aste N, Pau M, Aste N, Biggio P. Pityriasis rotunda: a survey of 42 cases observed in Sardinia, Italy. Dermatology. 1997;194:32.

2. Badri T, Hafsi W. Pityriasis rotunda. StatPearls. Treasure Island (FL): StatPearls Publishing; StatPearls Publishing LLC.2019.

3. Al-Refu K, Al-Tarawneh A, Odeibat H. Pityriasis rotunda. a clinical study in Jordan: experience of 10 years. Int J Dermatol. 2018;57:759-62.

4. Al-Refu K, Al-Tarawneh A, Odeibat H. Pityriasis rotunda. A clinical study in Jordan: experience of 10 years. Int J Dermatol. 2018; 57:759-62.

5. Zur L. Pityriasis Rotunda Diagnosed in Canada: Case Presentation and Review of the Literature. J Cut Med Surg. 2013;17:426-8.

Copyright by Selma El Kadiri, et al. This is an open-access article distributed under the terms of the Creative Commons Attribution License, which permits unrestricted use, distribution, and reproduction in any medium, provided the original author and source are credited.

Source of Support: Nil, Conflict of Interest: None declared. 